Web Jurnal:

http://ejournal.kemenperin.go.id/jli

Kementerian

Perındustrian

REPUBLIK INDONESIA

\title{
Physical properties of a natural foam made from gambier: influence of proportion of gambier extract used
}

\section{Pengaruh komposisi ekstrak gambir pada pembuatan dan sifat fisik busa alami berbasis gambir}

Inda Three Anova*1, Anwar Kasim², Tuty Anggraini'

1 Balai Riset dan Standardisasi Industri Padang

Jl. Raya LIK No. 23 Ulu Gadut, Padang, Indonesia

2 Fakultas Teknologi Pertanian Universitas Andalas

Kampus Limau Manis, Padang, Indonesia

* e-mail: indova99@gmail.com

\begin{tabular}{|c|c|}
\hline INFO ARTIKEL & ABSTRACT \\
\hline Article history: & Tannin made from gambier extract contains hydroxyl groups and so can be modified to \\
\hline $\begin{array}{l}\text { Submitted: } \\
\text { 23 Juli } 2018\end{array}$ & synthesize polymers. Gambier extract has a high tannin content that contains \\
\hline Revised: & make a polymer foam which can be used as an insulator for heat and sound, an absorber \\
\hline 22 November 2018 & of heavy metal pollutants and for protective packaging. This study investigates the \\
\hline Published: & utilization of gambier in the manufacture of foam and determines the physical properties \\
\hline & $\begin{array}{l}\text { of the foam produced. The study was conducted using ethanol to produce the gambier } \\
\text { extract from leaves of the plant which was used in the proportions of } 14 \%, 24 \% \text {, and } 34 \%\end{array}$ \\
\hline $\begin{array}{l}\text { Keywords: } \\
\text { tannin; } \\
\text { gambier extract; } \\
\text { foam }\end{array}$ & $\begin{array}{l}\text { by weight to make different foam samples. Foam produced from } 24 \% \text { gambier extract } \\
\text { had optimum qualities with a density value of } 0.34 \mathrm{~g} / \mathrm{cm}^{3}, \mathrm{pH} 6.83 \text {, compressive strength } \\
\text { of } 0.14 \mathrm{~kg} / \mathrm{cm}^{2} \text {, thermal conductivity of } 5.52 \mathrm{~W} / \mathrm{m}^{\circ} \mathrm{C} \text {, and was semi-flexible foam. }\end{array}$ \\
\hline
\end{tabular}

\begin{abstract}
ABSTRAK
Salah satu senyawa kelompok OH yang dapat dimodifikasi untuk tujuan sintesis polimer adalah tanin dari ekstrak gambir. Ekstrak gambir dengan kandungan tanin tinggi dapat dimodifikasi untuk pembuatan busa yang dapat digunakan sebagai bahan isolator panas, suara, dan penyerap logam serta untuk pengemasan. Pada pembuatan busa berbasis gambir, tanin yang terdapat pada gambir berfungsi sebagai isolasi materi yang terjadi karena polikondensasi dari poliflavonoid tanin dengan bahan tambahan lainnya. Penelitian ini bertujuan untuk memanfaatkan gambir dalam pembuatan busa dan mengetahui sifat fisik busa yang dihasilkan. Penelitian dilakukan dengan tahap awal ekstraksi gambir menggunakan etanol. Perlakuan penelitian adalah pemakaian ekstrak gambir 14\%, 24\%, dan 34\%. Hasil penelitian menunjukkan bahwa busa yang dihasilkan dari pemakaian ekstrak gambir $24 \%$ memiliki nilai densiti $0,34 \mathrm{~g} / \mathrm{cm}^{3}, \mathrm{pH} \mathrm{6,83,} \mathrm{kuat}$ tekan $0,14 \mathrm{~kg} / \mathrm{cm}^{2}$, konduktivitas termal $5,52 \mathrm{~W} / \mathrm{m}^{\circ} \mathrm{C}$, dan busa dapat digolongan sebagai busa semi fleksibel.
\end{abstract}

Kata kunci:

tanin;

ekstrak gambir;

busa

(C) 2018 Penulis. Dipublikasikan oleh Baristand Industri Padang. Akses terbuka dibawah lisensi CC BY-NC-SA

\section{Introduction}

Gambier is an extract from the leaves of Uncaria gambier and is sold on the market as cylindrical chunks of crude extract. Gambier is widely used as an industrial raw material in the textile industry, cosmetic industry, pharmaceutical industry, and as an additive to food products (Rauf et al., 2010). In traditional societies, gambier is used as a dye for textiles and rubber and for leather tanning (Kassim, M. Jain et al., 2013).

Gambier contains natural polyphenol compounds including tannins. Complex phenolic compounds such as tannins dissolve in polar solvents such as water (especially in hot water), methanol, ethanol, and acetone (Irianty and Verawati, 2012). 
The reactivity of tannins is due to the presence of hydroxyl radicals on in the phenolic group. There are two types of tannins; hydrolyzed tannins and condensed / thick tannins. Condensed tannins consist of flavonoid complexes, which form oligomers and polymers. More than $90 \%$ of the world's commercial production of tannins are condensed tannins which are used in a variety of industrial applications such as tanning or wood adhesives (Arbenz and Avérous, 2015; Benyahya et al., 2014; Kasim et al., 2014).

Tannin types derived from flavonol in gambier are condensed tannins that cannot be hydrolyzed either with acids or bases, but can form stable complex compounds based on hydrogen bond formation and hydrophobic interactions with proteins and polysaccharides (Hagerman, 2002).

The presence of $\mathrm{OH}$ groups in tannins allows for chemical modification in the form of polymer synthesis to produce adhesives for wood, epoxy resins, and foams. Considerable research on the use of tannins for foammaking has been conducted in the last few years (Basso et al., 2013a, 2013b, 2013b; Čop et al., 2015a; Jana et al., 2015; Lacoste et al., 2015; Lacoste et al., 2013a, 2013c, Li et al., 2012b, 2013, 2012a; Martinez de Yuso et al., 2014; Szczurek et al., 2014a; Thébault et al., 2014).

It has been found that the resulting foam has a low conductivity coefficient (Celzard et al., 2010; Lacoste et al., 2014). It also has a higher level of renewable compounds than polyurethane foam. Foam from tannins are at least as chemical and fire resistant as phenolformaldehyde foams (Čop et al., 2015b) and can be used as a heat or sound insulators and to absorb heavy metal ions (Sánchez-Martín et al., 2013). Procyanidin condensed tannin foams have been made from Pinus pinaster tannin and characterized. Tannin foams have also been made using egg albumin in a thick aqueous solution with flavonoid tannins (Lacoste et al., 2015, 2014).

Research and development has been carried out on the manufacture of tannin-based foams for heat insulation using different methods and formulations to modify the porosity of the foam. For instance, tannins from mimosa trees have been dissolving in water and stirred. PEG-35 (castor oil) was then added to maintain aeration in the solution so that the liquid foam continued to expand. Hexamethylenatetraamine (hexamine) has been used while for liquid foam hardened to preserve stability and P-Toluene Sulfonic Acid (pTSA) as catalysts to accelerate the reaction (Szczurek et al., 2014b).

The chemistry of the production of foam relies on a decomposition reaction using toxic and non-natural reagents, and the use of additives, such as the methylene4,4 di phenyl isocyanate polymer which releases carbon dioxide when forming urethane bridges. Chemical methods are generally used in the production of polyurethane foams (Lacoste et al., 2015). However, making foam mechanically with a vigorous stirring system causes the formation of gas to disperse through the liquid system in a homogeneous manner. The liquid foam is then compacted using high temperatures ( $\mathrm{Li}$ et al., 2012c; Szczur et al., 2013).
Tannins from pine bark have been used for foam production in Europe (Čop et al., 2015b). Manufacture of tannin-based foam from Quebracho wood (Schinopsis lorentzii), Radiata pine (Pinus radiata), Maritime pine (Pinus pinaster), and Pine wood (Picea abies) used protein from egg albumin which is an effective additive as tannins binding strongly to proteins and can precipitate proteins so maintaining porosity and producing a foam that is more porous than with alternative additives (Lacoste et al., 2015). Foam has also been made from tannins from the leaves of Quebracho (Schinopsis balansae) and Acacia (Acacia mearnsii) which predominantly contain the tannins prorobinetinidin / profisetinidin (Lacoste et al., 2014, 2013b; Szczurek et al., 2014b; Tondi et al., 2009) and from pine tree bark (Pinus radiata and Pinus pinaster) (Lacoste et al., 2014, 2013b).

The study aims to continue foam technology research using natural renewable raw materials by utilizing tannins from gambier and identifying the physical properties of the foam produced.

\section{Method}

Gambier used in this study was from Lima Puluh Kota, albumin was used as an additive, hexamine as the hardener, and Toluene Sulfonic Acid (pTSA) as a catalyst, distilled water as the gambier solvent. The equipment used included mixers, ovens, scales, 80 mesh sieves, Hanna digital pH meter, Cesare Galdabini Gallarate (Italy) compressive strength test equipment, digital Texture Analyzer test equipment type CT3 Brookfield Made in USA, glass beaker, measuring cup, spatulas, analytical balance (presica), pyrometer, and stopwatch.

\subsection{Gambier preparation}

The gambier was ground to a 40 mesh size, then the extraction process was carried out using ethanol solvent (1:10). The solution was stirred using a magnetic stirrer for \pm 1 hour and filtered. Solvent separation used a vacuum rotary evaporator. The resulting gambier extract powder was then ground to pass through an 80 mesh sieve. The purpose of gambier extraction is because in making foam it is expected that gambier extract has a high tannin content and ethanol is a very good solvent for natural ingredients.

\subsection{Making foam}

Gambier-based natural foam was made according to the method of (Lacoste et al., 2015) at room temperature $\left(25-26^{\circ} \mathrm{C}\right)$ and about $70 \%$ relative humidity. First the chosen amount of gambier extract (G1: 14\%, G2: $24 \%, G 3: 34 \%$ ) was mixed \pm 15 minutes with hexamine, pTSA and water to form an emulsion in the form of a liquid foam. PTSA is used as a catalyst or to accelerate the reaction in the manufacture of foam. Making foam under acidic or alkaline conditions accelerates the condensation reaction between the amine and amide groups and the position of covalent bonds. Then the mixture was put into a glass beaker as a mold 
and heated in an oven at $100^{\circ} \mathrm{C}$ for \pm 2 hours. After cooling the foam was cut according to the size needed for physical testing.

\subsection{Foam characteristics}

2.3.1. Behavior at room temperature (Lacoste et al., 2015)

The foam samples were placed at room temperature $\left(25-26^{\circ} \mathrm{C}, 65-70 \% \mathrm{RH}\right)$ for one week. Any changes in shape, size and color were observed and noted.

\subsection{2. pH (Lacoste et al., 2015)}

Measurement of $\mathrm{pH}$ of foam was undertaken by cutting foam into $2 \mathrm{~cm} \times 2 \mathrm{~cm} \times 2 \mathrm{~cm}$ cubes, then soaking and wringing it in water, the filtrate (filtered with filter paper) $\mathrm{pH}$ was measured with a $\mathrm{pH}$ meter that had been calibrated with $\mathrm{pH} 7$ and $\mathrm{pH} 4$ buffer solutions.

\subsubsection{Thermal conductivity (Astuti, 2015)}

The sample was placed between two cylindrical iron plates and placed on a heat source (electric stove) and heated for 10 minutes. The temperature at the bottom iron plate, in the foam and at the top iron plate was recorded (T1, T2, T3). The experiment was conducted in triplicate. P. $\Delta \mathrm{T}$ was used to determine the thermal conductivity of the synthesized tannin-albumin gambier foam using the equation (1).

$$
k=\frac{k \text { besixr } 2 x(T 1-T 2) x t}{r 2 x(T 2-T 3) x t \text { besi }}
$$

$\mathrm{k}$ : thermal conductivity $\left(\mathrm{W} / \mathrm{m}^{\circ} \mathrm{C}\right), \mathrm{r}$ : radius of the cylindrical foam sample; $\mathrm{t}$ : thickness of sample, $\Delta \mathrm{T}$ : temperature difference between top and bottom, $\mathrm{k}$ besi
(Fe): thermal conductivity of iron, $\mathrm{t}$ besi: thickness of iron.

\subsubsection{Density of the foam (Lacoste et al., 2015)}

Density of foam was calculated gravimetrically using the equation (2).

$$
p=\frac{m}{v}
$$

$\mathrm{m}$ : mass $(\mathrm{g}), \mathrm{v}$ : total volume $\left(\mathrm{m}^{3}\right)$

\subsubsection{Mechanical resistance/ testing of compressive strength (Lacoste et al., 2015)}

Mechanical resistance was measured using a $2 \mathrm{kN}$ universal test machine Cesare Galdabini Gallarate (Italy). The sample $(8 \mathrm{~cm}$ high, $8 \mathrm{~cm}$ diameter) was pressed with a load speed of $0.04 \mathrm{~mm} / \mathrm{sec}$. Digital readings were taken until fracture. The compressive strength is calculated by the formula (3).

$$
x=\frac{F \text { maks }}{A}
$$

$\mathrm{x}$ : Compressive strength $\left(\mathrm{kg} / \mathrm{cm}^{2}\right), \mathrm{F}$ max.: Maximum load on sample, A: Cross sectional area of test sample $\left(\mathrm{cm}^{2}\right)$.

\section{Results and discussion \\ 3.1. Behavior at room temperature}

The color, texture, mass and size of the sample at the beginning of the observation period are recorded in table 1.

\begin{tabular}{|c|c|c|c|c|c|c|}
\hline \multirow{2}{*}{ Treatment } & \multirow{2}{*}{ Observation } & \multicolumn{4}{|c|}{ Day after manufacture } & \multirow{2}{*}{ Photograph of foam } \\
\hline & & 1 & 3 & 5 & 7 & \\
\hline \multirow{4}{*}{$\begin{array}{l}\text { G1 } \\
\text { (gambier extract } \\
14 \% \text { ) }\end{array}$} & Color & Brown & Brown & Brown & Brown & \\
\hline & Texture & Porous & Porous & Porous & Porous & \\
\hline & Mass (g) & 26.55 & 26.21 & 24.79 & 23.64 & \\
\hline & Size $(\mathrm{cm})$ & $7 \times 6.5$ & $7 \times 6.5$ & $7 \times 6.5$ & $7 \times 6.5$ & \\
\hline \multirow{4}{*}{$\begin{array}{l}\text { G2 } \\
\text { (gambier extract } \\
24 \% \text { ) }\end{array}$} & Color & Brown & Brown & Brown & Brown & \\
\hline & Texture & Porous & Porous & $\begin{array}{l}\text { Porous and } \\
\text { quite hard }\end{array}$ & $\begin{array}{l}\text { Porous and } \\
\text { quite hard }\end{array}$ & \\
\hline & Mass (g) & 30.81 & 30.35 & 30.16 & 28.23 & \\
\hline & Size $(\mathrm{cm})$ & $8 \times 7$ & $8 \times 7$ & $8 \times 7$ & $8 \times 7$ & \\
\hline \multirow{4}{*}{$\begin{array}{l}\text { G3 } \\
\text { (gambier extract } \\
34 \% \text { ) }\end{array}$} & Color & Brown & Brown & Brown & Brown & \\
\hline & Texture & quite dense & & dense & dense & \\
\hline & Mass (g) & $35 ., 01$ & 34.86 & 34.72 & 33.68 & \\
\hline & Size $(\mathrm{cm})$ & $9 \times 8$ & $9 \times 8$ & $9 \times 8$ & $9 \times 8$ & \\
\hline
\end{tabular}

Table 1

Results of observation of behavior of foam at room temperature over 7 days

key: size (length $\times$ height) 
All three treatments resulted in a brown foam the color of the raw gambier. According to the research conducted by (Lacoste et al., 2015), natural foam from tree tannins took the colour of the original tannin in the raw material; light brown from Pinnus radiata, Pinnus pinaster, and Pinnus abies tannins and black from Quebracho tannin.

Table 1 also shows the texture of the foam from the three treatments. Foam from 14\% gambier (G1) and $24 \%$ gambier (G2) was not as solid in texture as $34 \%$ gambier (G3). This was obvious from the handfeel of the foam. Tightness of texture increased with gambier content. No foam samples changed in size over the seven day observation period.

The weight of the gambier foam appears to decrease over the seven observation days. This is probably due to the foam becoming drier after being placed at room temperature. After the heating process, the foam still has a fairly high moisture content some of which evaporates. After 7 days the weight of the foam begins to stabilize suggesting that it has dried out. The foam also became denser or harder as this happened. Increasing concentration of tannin used produced a heavier and more dense foam. This is consistent with the research conducted by (Szczurek et al., 2014b), who found similar changes in foam with tannin concentration especially in terms of density affecting the porosity and foam size.

\subsection{Foam acidity}

The results of the $\mathrm{pH}$ observations of the gambier foam samples can be seen in Table 2. The $\mathrm{pH}$ values were all similar indicating that gambier extract content has minimal effect on the $\mathrm{pH}$ value of the resulting gambier foam. The near neutral values of $\mathrm{pH}$ suggest the use of the acidic pTSA catalyst does not result in overly acidic foam.

The used of pTSA is only as a catalist or to accelerate the reaction in making foam. The making foam in acid or base condition will accelerate the condesed reaction between amine and amide group, and covalent bonding position (Lacoste et al., 2015).

Table 2

Physical characteristics of the gambier foams

\begin{tabular}{|c|c|c|c|c|}
\hline $\begin{array}{l}\text { Treat- } \\
\text { ment }\end{array}$ & $\mathrm{pH}$ & $\begin{array}{l}\text { Thermal } \\
\text { Conductivity } \\
\left(\mathrm{W} / \mathrm{m}^{\circ} \mathrm{C}\right)\end{array}$ & $\begin{array}{l}\text { Density } \\
\left(\mathrm{g} / \mathrm{cm}^{3}\right)\end{array}$ & $\begin{array}{l}\text { Compressive } \\
\text { strength } \\
\left(\mathrm{kg} / \mathrm{cm}^{2}\right)\end{array}$ \\
\hline G1 & 6.46 & 4.29 & 0.31 & 0.11 \\
\hline G2 & 6.83 & 5.52 & 0.34 & 0.14 \\
\hline G3 & 6.73 & 6.73 & 0.42 & 0.26 \\
\hline
\end{tabular}

In alkaline conditions the reaction between methylene and poly methylene which connects tannins to tannins is more dominant, and between tannins and proteins less dominant, and between proteins negligible. In the acidic conditions the inter and intramolecular reactions between methylene and polymethylene groups and protein amides from albumin will be dominant, less dominant between tannins and proteins and negligible between tannin molecules (Lacoste et al., 2015) so acid accelerates the reaction between tannins and albumin in making foam. However, use of an acid catalyst does not have a significant effect on the $\mathrm{pH}$ of the foam produced.

\subsection{Foam thermal conductivity $\left(\mathrm{W} / \mathrm{m}^{\circ} \mathrm{C}\right)$}

The results of the measurement of foam thermal conductivity in Table 2 show that with the increasing concentration of gambier extract, the thermal conductivity increased. The highest conductivity value was obtained in the treatment using $34 \%$ gambier extract concentration and the lowest thermal conductivity value for the most use of gambier extract was $14 \%$. This is because the use of $14 \%$ gambier extract produced a more porous and less dense foam that was less able to prevent heat transfer heat. The thermal conductivity of porous materials such as foam is determined by its geometric structure and is strongly influenced by foam density values (Lacoste et al., 2015).

Factors that influence the value of thermal conductivity of a foam include temperature, density, porosity and moisture content. Table 2 shows a relationship between the thermal conductivity with the density of the foam produced. The lower the value of thermal conductivity obtained, the lower the density value. According to (Čop et al., 2015a), for thermal or sound insulator application and for package surface protection foam with a lower density is better.

\subsection{Foam density $\left(\mathrm{g} / \mathrm{cm}^{3}\right)$}

The density value of the foam samples can be seen in Table 2 and ranges from $0.42 \mathrm{~g} / \mathrm{cm}^{3}$ to $0.31 \mathrm{~g} / \mathrm{cm}^{3}$. The highest density value was obtained using gambier extract $34 \%$ (G3) and the lowest was obtained by using gambier extract $14 \%$ (G1). The higher the gambier extract content the higher the density value of the foam produced.

As tannin concentration increases the foam structure becomes tighter and the bonding between the tannin, albumen and, hexamine to form more complete complexes. Complex formation is highly dependent on the concentration of tannins, water, and additives used in the process as well as other factors, such as aeration/stirring, use of pTSA, water use and maturation process (Li et al., 2012c).

The denser the foam, the tighter the pore structure so that the ability to conduct heat gets higher. (Firdaus, 2014) reported that the density value determines the value of the mechanical strength of foam, where the higher the density value correlated with good mechanical strength.

\subsection{Compressive strength $\left(\mathrm{kg} / \mathrm{cm}^{2}\right)$}

Table 2 shows that the values of gambier foam compressive strength follow the same pattern as the density and thermal conductivity values which increase with increasing gambier concentrations. The highest 
value of compressive strength, $0.26 \mathrm{~kg} / \mathrm{cm}^{2}$, was obtained by using $34 \%$ gambier concentration.

The mechanical strength of foam is influenced by tannin concentration, additives (Hexamine), the albumen used, water, catalyst use (pTSA), temperature and mixing conditions (Lacoste et al., 2015). Strong stirring will help accelerate the formation of complex crossbonding between the materials used. According to (Szczurek et al., 2014b), an Amino(imino)methyl reaction originating from the decomposition of hexamine and tannins creates benzyl amine bridges cross-linking between gambier and Hexamine as shown in Figure 1.

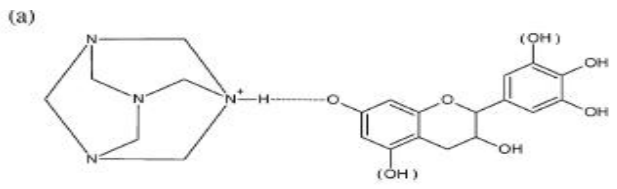

(b)
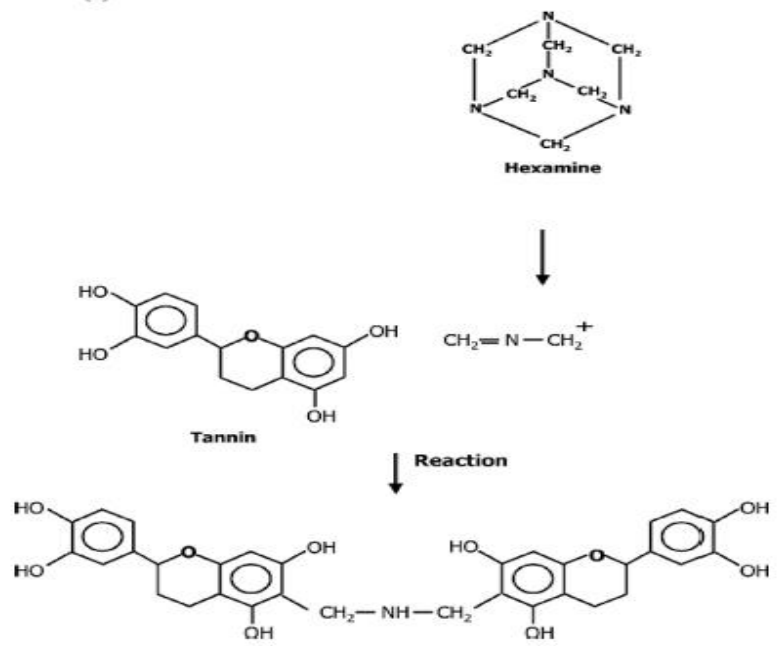

Figure 1. Reaction between a flavonoid tannin and hexamine: (a) formation of complex, (b) cross linking through the formation of a benzylamine bridge by a Amino(imino)methyl reaction (Szczurek et al., 2014b).

\section{Conclusion}

Tannin from gambier extract can be used to make a natural semi-flexible foam based using albumen as an addition, hexamine as hardener and pTSA acid as a catalyst. The proportion of gambier extract used did not affect the $\mathrm{pH}$ of the foam, but thermal conductivity, compressive strength and the density increases with proportion of gambier extract used. Optimal properties for a flexible foam were obtained with $24 \%$ gambier extract, with a value of $\mathrm{pH} 6.83$, thermal conductivity $5.52 \mathrm{~W} / \mathrm{m}^{\circ} \mathrm{C}$, density $0.34 \mathrm{gr} / \mathrm{cm}^{3}$, and compressive strength of $0.14 \mathrm{~kg} / \mathrm{cm}^{2}$. A higher proportion of gambier tannin results in a foam that is stronger and insulates better but is less flexible. Based on density value, natural gambier foam can be grouped in semi-flexible foam.

\section{Acknowledgements}

Thanks to Mr. Hendri Muchtar and Titi Putri Ningsih for giving many suggestions and helping with this research activity so that it went well and smoothly.

\section{References}

Arbenz, A., Avérous, L., 2015. Oxyalkylation of gambier tannin-synthesis and characterization of ensuing biobased polyols. Ind. Crops Prod. 67, 295304. https://doi.org/10.1016/j.indcrop.2015.01.073

Astuti, I.A., 2015. Penentuan konduktivitas termal logam tembaga, kuningan, dan besi dengan metode gandengan. Pros. Semin. Nas. Fis. dan Pendidik. Fis. Ke-6 6, 30-34.

Basso, M.C., Giovando, S., Pizzi, A., Celzard, A., Fierro, V., 2013a. Tannin/furanic foams without blowing agents and formaldehyde. Ind. Crops Prod. 49, 1722. https://doi.org/10.1016/j.indcrop.2013.04.043

Basso, M.C., Pizzi, A., Celzard, A., 2013b. Influence of formulation on the dynamics of preparation of tannin-based foams. Ind. Crops Prod. 51, 396-400. https://doi.org/10.1016/j.indcrop.2013.09.013

Benyahya, S., Aouf, C., Caillol, S., Boutevin, B., Pascault, J.P., Fulcrand, H., 2014. Functionalized green tea tannins as phenolic prepolymers for biobased epoxy resins. Ind. Crop. Prod. S., Aouf, C., Caillol, S., Boutevin, B., Pascault, J. P., Fulcrand, H. (2014). Funct. green tea Tann. as phenolic prepolymers bio-based epoxy resins. Ind. Crop. Prod. 53, 296-307. https 53, 296-307. https://doi.org/ 10.1016/j.indcrop.2013.12.045

Celzard, A., Zhao, W., Pizzi, A., Fierro, V., 2010. Mechanical properties of tannin-based rigid foams undergoing compression. Mater. Sci. Eng. A 527, 4438-4446. https://doi.org/10.1016/j.msea.2010. 03.091

Čop, M., Gospodarič, B., Kemppainen, K., Giovando, S., Laborie, M.P., Pizzi, A., Sernek, M., 2015 a. Characterization of the curing process of mixed pine and spruce tannin-based foams by different methods. Eur. Polym. J. 69, 29-37. https://doi.org/10.1016/ j.eurpolymj.2015.05.020

Čop, M., Lacoste, C., Conradi, M., Laborie, M.P., Pizzi, A., Sernek, M., 2015b. The effect of the composition of spruce and pine tannin-based foams on their physical, morphological and compression properties. Ind. Crops Prod. 74, 158-164. https://doi.org/ 10.1016/j.indcrop.2015.04.009

Firdaus, F.E., 2014. Synthesis and characterization of soy-based polyurethane foam with utilization of ethylene glycol in polyol. Makara J. Technol. 18, 1116. https://doi.org/10.7454/mst.v18i1.2937

Hagerman, A., 2002. Tannin chemistry handbook. Livro 116. https://doi.org/10.1038/134611a0

Irianty, R.S., Verawati, R., 2012. Variasi komposisi pelarut metanol-air pada ekstraksi daun gambir (Uncaria gambir Roxb) 46-49. 
Jana, P., Fierro, V., Pizzi, A., Celzard, A., 2015. Thermal conductivity improvement of composite carbon foams based on tannin-based disordered carbon matrix and graphite fillers. Mater. Des. 83, 635-643. https://doi.org/10.1016/j.matdes.2015.06.057

Kasim, A. ; Asben, A. ; Mutiar, S., 2014. Kajian kualitas gambir dan hubungannya dengan karakteristik kulit tersamak. Maj. Kulit, Karet, dan Plast. 31, 55-63.

Kassim, M. Jain .; Hussin, M. Hazwan .; A. Achmad.; Dahon, N. Hazwani .; Suan, T. Kim and Hamdan, H.S., 2013. Determination of total phenol, condensed tannin and flavonoid contents and antioxidant activity of Uncaria gambir extracts. J. Chem. Inf. Model. 53, 1689-1699. https://doi.org/10.1017/ CBO9781107415324.004

Lacoste, C., Basso, M.C., Pizzi, A., Celzard, A., Ella Ebang, E., Gallon, N., Charrier, B., 2015. Pine (P. pinaster) and quebracho (S. lorentzii) tannin-based foams as green acoustic absorbers. Ind. Crops Prod. 67, 70-73. https://doi.org/10.1016/j.indcrop.2014. 12.018

Lacoste, C., Basso, M.C., Pizzi, A., Laborie, M.-P., Celzard, A., Fierro, V., 2013a. Pine tannin-based rigid foams: Mechanical and thermal properties. Ind. Crops Prod. 43, 245-250. https://doi.org/10.1016/ J.INDCROP.2012.07.039

Lacoste, C., Basso, M.C., Pizzi, A., Laborie, M.P., Celzard, A., Fierro, V., 2013b. Pine tannin-based rigid foams: Mechanical and thermal properties. Ind. Crops Prod. 43, 245-250. https://doi.org/10.1016/ j.indcrop.2012.07.039

Lacoste, C., Basso, M.C., Pizzi, A., Laborie, M.P., Garcia, D., Celzard, A., 2013c. Bioresourced pine tannin/furanic foams with glyoxal and glutaraldehyde. Ind. Crops Prod. 45, 401-405. https://doi.org/10.1016/j.indcrop.2012.12.032

Lacoste, C., Čop, M., Kemppainen, K., Giovando, S., Pizzi, A., Laborie, M.P., Sernek, M., Celzard, A., 2015. Biobased foams from condensed tannin extracts from Norway spruce (Picea abies) bark. Ind. Crops Prod. 73, 144-153. https://doi.org/10.1016/ j.indcrop.2015.03.089

Lacoste, C., Pizzi, A., Laborie, M., Celzard, A., 2014. Pinus pinaster tannin / furanic foams: Part II . Physical properties. Ind. Crop. Prod. 61, 531-536. https://doi.org/10.1016/j.indcrop.2014.04.034

Lacoste, Basso, M.C., Pizzi, A., Celzard, A., Laborie, M., 2015. Natural albumin / tannin cellular foams. Ind. Crop. Prod. 73, 41-48. https://doi.org/10.1016/ j.indcrop.2015.03.087

Li, X., Pizzi, A., Cangemi, M., Fierro, V., Celzard, A., 2012a. Flexible natural tannin-based and proteinbased biosourced foams. Ind. Crops Prod. 37, 389-
393. https://doi.org/10.1016/j.indcrop.2011.12.037

Li, X., Pizzi, A., Cangemi, M., Navarrete, P., Segovia, C., Fierro, V., Celzard, A., 2012b. Insulation rigid and elastic foams based on albumin. Ind. Crops Prod. 37, 149-154. https://doi.org/10.1016/j.indcrop.2011. 11.030

Li, X., Pizzi, A., Cangemi, M., Navarrete, P., Segovia, C., Fierro, V., Celzard, A., 2012c. Insulation rigid and elastic foams based on albumin. Ind. Crops Prod. 37, 149-154. https://doi.org/10.1016/j.indcrop.2011. 11.030

Li, X., Srivastava, V.K., Pizzi, A., Celzard, A., Leban, J., 2013. Nanotube-reinforced tannin/furanic rigid foams. Ind. Crops Prod. 43, 636-639. https://doi.org/10.1016/j.indcrop.2012.08.008

Martinez de Yuso, A., Lagel, M.C., Pizzi, A., Fierro, V., Celzard, A., 2014. Structure and properties of rigid foams derived from quebracho tannin. Mater. Des. 63, 208-212. https://doi.org/10.1016/j.matdes. 2014.05.072

Rauf, R., Santoso, U., 2010. Aktivitas penangkapan radikal DPPH ekstrak gambir (Uncaria gambir Roxb.). Teknologi Pangan dan Hasil pertanian. Agritech 30, 1-5.

Sánchez-Martín, J., Beltrán-Heredia, J., DelgadoRegaña, A., Rodríguez-González, M.A., RubioAlonso, F., 2013. Optimization of tannin rigid foam as adsorbents for wastewater treatment. Ind. Crops Prod. 49, 507-514. https://doi.org/10.1016/j.indcrop. 2013.05.029

Szczur, A, Fierr, V., Pizzi, A, 2013. Mayonnaise, whipped cream and meringue, a new carbon cuisine. Carbon N. Y. 8, 245-248. https://doi.org/10.1016/ j.carbon.2013.02.056

Szczurek, A., Fierro, V., Pizzi, A., Stauber, M., Celzard, A., 2014a. A new method for preparing tannin-based foams. Ind. Crops Prod. 54, 40-53. https://doi.org/ 10.1016/j.indcrop.2014.01.012

Szczurek, A., Fierro, V., Pizzi, A., Stauber, M., Celzard, A., 2014b. A new method for preparing tannin-based foams. Ind. Crops Prod. 54, 40-53. https://doi.org/ 10.1016/j.indcrop.2014.01.012

Thébault, M., Pizzi, A., Dumarçay, S., Gerardin, P., Fredon, E., Delmotte, L., 2014. Polyurethanes from hydrolysable tannins obtained without using isocyanates. Ind. Crops Prod. 59, 329-336. https://doi.org/10.1016/j.indcrop.2014.05.036

Tondi, G., Zhao, W., Pizzi, A., Du, G., Fierro, V., Celzard, A., 2009. Tannin-based rigid foams: A survey of chemical and physical properties. Bioresour. Technol. 100, 5162-5169. https://doi.org/ 10.1016/j.biortech.2009.05.055 